\title{
Do venture capitalists give founders their walking papers? ${ }^{\text {th }}$
}

\author{
Diana Heger ${ }^{\mathrm{a}, 1}$, Tereza Tykvová ${ }^{\mathrm{b}, *}$ \\ a Centre for European Economic Research (ZEW), Dept. Industrial Economics and International Management, P.O. Box 103443, D-68034 Mannheim, Germany \\ b Centre for European Economic Research (ZEW), Dept. International Finance and Financial Management, P.O. Box 103443, D-68034 Mannheim, Germany
}

\section{A R T I C L E I N F O}

\section{Article history:}

Received 16 January 2007

Received in revised form 9 July 2009

Accepted 10 July 2009

Available online 19 July 2009

\section{JEL classification:}

G24

G32

Keywords:

Venture capital

Executive turnover

\begin{abstract}
A B S T R A C T
We investigate the impact of venture capitalists on the turnover of executives within a sample of nearly 46,500 German high-tech start-up companies founded between 1995 and 2004. We confirm that the presence of VCs increases the chances that the company will change the structure of its initial executive team. For the purposes of our analysis, we distinguish between different types of changes (somebody is replaced, the team is enlarged, the team shrinks). Additionally, we take a closer look at the subsample of venture-backed companies. We find that a small distance between the VCs and the companies they finance, as well as a larger total stake in the company owned by the VCs, goes hand-in-hand with an increased probability of changes in the initial executive teams.
\end{abstract}

(c) 2009 Elsevier B.V. All rights reserved.

\section{Introduction}

Founders with innovative ideas often lack two essential factors for the transformation of their concepts into a profit-making venture: money and managerial experience. Particularly in the later stages of a company's existence, after the first product has already been developed, the technical know-how of the founding management team is often less crucial. In this phase, extensive managerial know-how is decisive for the commercialization and, thus, the success of the company. Whereas founders are typically technically-oriented entrepreneurs with little management experience, professional managers have industry expertise, knowledge of the relevant market, established contacts and know-how in marketing, financial and human resource management. The replacement of one or more executives or an enlargement of the founding team with experienced professional managers is therefore often critical for the company's commercial success. In some cases, reducing the number of executives may improve efficiency.

This study looks into the role of venture capitalists (VCs) in this process. Besides the provision of capital, VCs are actively involved in the management of their portfolio companies. Whereas most of the VCs' day-to-day activities remain unobservable, one of their most striking actions, namely the decision to change the structure of the initial executive team, is immediately apparent. The VC's right to influence the structure of the executive team is a typical part of the contract concluded between the VC and the company (see e.g. Sahlman, 1990; Tykvová, 2007 for an overview of contracts between VCs and their portfolio companies) and represents one of the key areas of their involvement.

Companies' founders themselves are usually not very pleased about leaving "their" company or appointing an outsider to a leading position. Therefore, we would expect companies without VCs' involvement to have a more reluctant attitude towards

\footnotetext{
is Financial support from the DFG (under grant no. Wa 825/7-1) is gratefully acknowledged. The authors are indebted to Creditreform for providing the data. The present version has benefited from comments by David Denis (the Editor), an anonymous referee, Georg Licht, participants at the IECER 2006 Conference in Montpellier and the DGF 2006 Conference in Oestrich-Winkel. Thorsten Doherr provided a string-based search algorithm helping us to identify VC-backed firms.

* Corresponding author. Tel.: +49621 1235147; fax: +49621 1235223.

E-mail addresses: heger@zew.de (D. Heger), tykvova@zew.de (T. Tykvová).

${ }^{1}$ Tel.: +49621 1235382 .
} 
changes in their executive teams. In contrast, VCs, who primarily care about the return on their investment and whose reputations suffer when they are involved in faltering companies, focus on the efficiency of their investments. For this reason, they are supposed to actively encourage changes in the original executive team if they come to the conclusion that additional know-how is needed or that the present team is working inefficiently. This is the starting point of our investigations.

Several existing analyses show that venture capitalists influence the composition of the board of directors and the choice of CEO. Rosenstein et al. (1993) demonstrate that the VCs' managing partners are often present on the board of directors. Boone et al. (2007) confirm the impact of VCs on board composition. In particular, venture capital financing leads to a larger fraction of outside directors. Baker and Gompers (2003) show that the probability that the founder remains as CEO decreases as the VC's bargaining power increases, using the VC's reputation as a proxy for bargaining power. Lastly, Hochberg (2008) demonstrates that venturebacked companies' boards of directors are more independent than those of similar non-venture-backed companies, and they are more likely to separate the roles of CEO and chairman.

Whereas most of the studies mentioned above deal with large, established companies that are publicly listed, we concentrate on start-up companies. A study thematically close to ours has been conducted by Hellmann and Puri (2002). They demonstrate that start-up companies that obtain venture capital are more likely to use business and professional contacts for recruiting personnel than their non-venture-backed counterparts. Compared to other financiers, VCs have a greater influence on the human resource policies of their portfolio companies at different levels. In particular, VCs affect the leadership at the very top of the companies. Venture-backed companies are more likely to appoint an outside CEO and this CEO replacement occurs earlier than in non-venture-backed companies. These findings confirm that VCs play an active role in their portfolio companies. Our results, which reflect the VCs' influence on changes within original executive teams, point in the same direction. We find a significant positive impact of VCs on the probability and the speed of change.

In a related paper, which deals with the features of the contracts between VCs and their portfolio companies and how they coincide with VCs' managerial activities, Kaplan and Strömberg (2004) demonstrate that in at least half of the investments in their sample, the VC expects to play an important role in recruiting new members for the executive team. Within our data set, a structural change within the original management team took place in $60.5 \%$ of the venture-backed companies (but only in $32.7 \%$ of companies that had not received venture capital). Besides the empirical evidence discussed above, several theoretical models deal with the impact of VCs on founder replacement (e.g. Hellmann, 1998; Bergemann and Hege, 1998; Chan et al., 1990; Aghion and Bolton, 1992).

A novel feature of our research is that we look into the kind of changes that take place within the original team. We distinguish between: (i) a replacement of one or more executives, (ii) a "pure" enlargement of the team and (iii) a "pure" reduction in the team size; each of these changes being the "right answer" in a different situation. For example, if the executive team needs additional know-how, replacement or enlargement would be expected. If the company wants to expand into new areas, team enlargement would probably be necessary. If the initial team is too large and inefficient, it may well shrink. We analyze whether each of these changes is more likely and occurs earlier in companies that obtain venture capital than in non-venture-backed companies. Even when we control for the endogeneity of venture capital financing, we find a positive impact of VCs on all kinds of changes.

An important contribution of our analysis is that we reduce the existing gap in empirical research on the impact of venture capital financing outside the US by using a data set on young German companies. Our data set consists of 46,459 high-tech startups founded between 1995 and 2004, of which 659 were venture-backed. Whereas the vast majority of studies in this area deal with the US market, we demonstrate that venture capitalists in Germany are very active investors who influence the composition of executive teams in a similar manner as in the US.

Besides the impact of venture capitalists on different kinds of changes within executive teams, we investigate the determinants behind these changes within the group of venture-backed companies. More specifically, we conjecture that certain VCs' characteristics (such as the VCs' stake or their proximity to the companies they fund) should influence the intensity of the VCs' involvement and, thus, the probability of a change in the composition of the executive team. Lerner (1995) demonstrates that the distance between a VC and its portfolio company is an important determinant of board membership. The larger the distance, the lower the probability of a VC's representative joining the board. Furthermore, Lerner (1995) shows that the stake held by the VC significantly influences the level of its involvement. These findings from the US market are consistent with our results for German high-tech start-ups: VCs' proximity to their portfolio companies and the size of their stakes are positively related to the probability and the speed of changes within the initial executive teams.

The rest of the paper is organized as follows. Section 2 gives an overview of our hypotheses. Section 3 describes our data set and presents some summary statistics. The results of the multivariate analysis for the whole sample are presented in Section 4 and those for the VC sample in Section 6. Section 5 takes the endogeneity of the VC financing into account. Section 7 concludes.

\section{Hypotheses}

Besides offering capital to companies, VCs also provide value-added services like management advice and support. Furthermore, they typically have extensive contractual control rights (see e.g. Kaplan and Strömberg, 2004), which enable them to actively intervene in the management of their portfolio companies. Such potential activity is motivated by the main aim of VCs, which is profit generation. If their returns appear to be at risk, the VCs immediately take action in order to improve their expected gains. Founders, on the other hand, also have issues other than monetary return in mind, such as their personal ties to the company.

One of the strongest ways in which VCs can intervene is to implement structural change within the executive team. Whereas the founders may dislike such disempowerment, the VCs may view the matter differently. Not only the VCs' focus on profit, but also 
their insider knowledge, experience in the relevant industry and, often, contacts to the pool of potential prospective managers, may increase the probability and speed of changes within venture-backed firms.

Hypothesis 1. Venture capital financing increases the probability that the company will change the structure of its initial executive team. It also reduces the time until a change in the initial executive team occurs.

After the analysis of differences between venture- and non-venture-backed companies, we move on to a more detailed investigation within the group of venture-backed companies. Thus, Hypotheses 2-4, which follow, address issues in the VC context and are subsequently tested for the subsample of venture-backed companies. We hypothesize that changes become more likely when the intensity of the VCs' involvement is high.

First, we assume that if the VC gets a larger slice of the pie, its incentives to actively work on increasing the pie's size get stronger. Thus, a larger stake in the company is expected to lead to a higher level of involvement on the part of the VCs (see e.g. Lerner, 1995) and consequently, to increase prospects for changes within the initial executive team. Moreover, we expect that the larger the stake VCs hold, the earlier a change in the team structure will occur.

Hypothesis 2. The larger the share of the company that is held by venture capitalists, the higher the probability and the speed of a change within the initial executive team.

Second, since governmental VCs play a crucial role in Germany (they hold shares in nearly 30\% of the venture-backed companies in our sample), we look at the differences between companies funded by governmental and non-governmental VCs. Several authors (e.g. Cumming et al., 2008) demonstrate that independent VCs generally tend to have a more pronounced role in corporate governance and monitoring within the companies they finance than captive VCs. Concerns are stated about the quality and extent of management involvement on the part of governmental VCs in particular (e.g. Engel and Heger, 2006). It is often assumed that governmental VCs are not able or willing to provide a sufficient contribution to the management of the companies because of their differing goals (e.g. employment growth, fostering of specific technology fields or regions), incentive structures and experience. Therefore, we presume that non-governmental VCs more often provoke a change in the executive team. Following the same line of reasoning, we conjecture that the time until a change occurs is longer for governmental VCs.

Hypothesis 3. A change in the initial executive team becomes more probable if the company is funded by a non-governmental venture capitalist. The change occurs faster if the company is funded by a non-governmental VC.

Finally, we analyze the impact of the VCs' geographical proximity to the companies they finance. We conjecture that monitoring intensity is likely to be sensitive to the distance between the VCs and their portfolio companies. We have two contradicting hypotheses with respect to this issue. In the spirit of Lerner (1995), one would expect the supervision of local businesses to be less costly and, thus, more intensive than that of more distant companies. VCs that are involved more closely are more likely to detect inefficiency. As a result, a change in the executive team should be more probable and occur faster in local than in distant portfolio companies.

Hypothesis 4a. The geographical proximity of the venture capitalist to the company increases the prospects for (and reduces the time until) change in the initial executive team.

In contrast to this, one could argue that a larger distance between the VCs and their portfolio companies induces the VCs to hire new executives in whom they trust more than the initial managers. This is due to the fact that the VCs cannot monitor the decisions of the managers in distant companies as intensively as if they were located nearby. As an alternative to intensive monitoring of the initial managers, which is very costly over long distances, remote VCs change the structure of initial executive teams in the portfolio companies by employing their confidants in a leading position.

Hypothesis $\mathbf{4 b}$. The geographical proximity of the venture capitalist to the company decreases the prospects for (and increases the time until) change in the initial executive team.

The two conflicting hypotheses on the impact of distance face a potential endogeneity problem. Therefore, one has to be cautious about causality. VCs might only agree on financing distant companies - the monitoring of which is more costly - if they expect that these companies require less intervention and monitoring. If this is the case, we would observe a negative correlation between the strength of involvement and distance, as suggested in Hypothesis $4 \mathrm{a}$.

\section{Data}

We use data from the ZEW Foundation Panel, which is constructed on the basis of data provided by the largest German credit rating agency, Creditreform (see Almus et al. (2000) for more details about the dataset). The ZEW Foundation Panel contains information on more than 5 million companies established after 1989 in Germany and on their owners. Our analysis deals with high-tech start-ups that were founded between 1995 and 2004. We use an industry-based definition of high-technology industries 
Table 1

List of variables.

\begin{tabular}{|c|c|}
\hline Replacement $(t)$ & Indicator of replacement within the initial team of executives \\
\hline Enlargement $(t)$ & $\begin{array}{l}\text { Indicator of whether or not the size of the initial executive team has increased } \\
\text { (without replacement, i.e. none of the initial members has left) }\end{array}$ \\
\hline Reduction ( $t$ ) & $\begin{array}{l}\text { Indicator of whether the number of initial executives has been reduced } \\
\text { (without replacement, i.e. no new member has come in) }\end{array}$ \\
\hline Time until replacement & Number of years between birth of the company and replacement \\
\hline Time until enlargement & Number of years between birth of the company and enlargement \\
\hline Time until reduction & Number of years between birth of the company and reduction \\
\hline$V c(t)$ & Indicator of whether the company is venture capital funded \\
\hline Vc share & Initial stake held by VCs ${ }^{*}$ \\
\hline Gov & Indicator of whether the company is financed only by governmental VCs \\
\hline Same district & Indicator of whether the VC and the company are in the same geographical district \\
\hline Acad & Indicator of whether at least one executive holds a university degree \\
\hline Age $(t)$ & Age of company in year $t$ \\
\hline Executive team & Number of executives at the birth date of the company \\
\hline Rating $(t)$ & Credit rating (given by Creditreform); best score: 100; worst score: 500 \\
\hline Worse rating $(t)$ & Indicator of whether credit rating has worsened by more than 50 points since the birth of the company \\
\hline Size $(t)$ & Number of employees \\
\hline Growth $(t)$ & Growth in the number of employees since the birth of the company \\
\hline East & Indicator of whether the company is located in Eastern Germany (former German Democratic Republic) \\
\hline Industry 1-5 & Industry dummies $* *$ \\
\hline Year 1995-2005 & Year dummies \\
\hline Access to $v c$ & Number of VCs divided by the number of high-tech start-ups in a district \\
\hline Number $v c$ & Number of VCs within a $50 \mathrm{~km}$ radius from the individual company \\
\hline
\end{tabular}

$(t)$ indicates a time-varying variable.

* Unfortunately, we do not have precise information on the development of the VCs' shares over time.

** For the definition of the industry dummies see Appendix B.

(see Appendix A for the description and a list of these industries). Our data set consists of 46,459 companies. Within this group, we identified 659 venture-backed businesses, which is $1.4 \%$ of the sample. ${ }^{2}$ Slightly more than a quarter of the companies from the VC sample are financed exclusively by governmental VCs. In $34.1 \%$ of the cases, the VC and the company are located in the same district. The VCs hold $47.5 \%$ of the shares on average.

We choose the 1995-2004 period because it was in the second half of the 1990s that the German high-tech industries began to flourish, along with the venture capital industry. For the recent years, the data may not be complete because there is a certain time lag before the companies enter the database. ${ }^{3}$

We concentrate on high-tech start-ups because this segment is characterized by substantial information asymmetries which make it difficult for entrepreneurs to close their financing gap by using external sources of finance. Venture capital is often seen as the last resort in this situation. In addition, the technical orientation of the start-up executive team and, thus, the need for change in the team composition may be more pronounced than in other, less technology-oriented companies.

The database does not explicitly cover information on venture capital financing. In order to identify whether a company has received venture capital, we use a computer-based search algorithm (for more details see Appendix C).

Table 1 comprises the descriptions of the dependent and independent variables included in the regressions. Table 2 contains the means and the standard deviations of our variables for the whole sample and for the subgroups of venture-backed and nonventure-backed companies. In addition, the $p$-values of the $t$-test for differences between the two subsamples (for binary variables: the $p$-values of the Wilcoxon rank-sum test) are given. There are significant differences in most of the variables.

In our dataset, we have information on owners, managing directors, board members, and general partners. For the purpose of this study, all of these people are defined as members of the executive team. We use three different dependent binary variables that capture the differing aspects of the changes within the executive team. First, the dependent variable replacement indicates whether one or more executives were replaced (i.e. one or more executives left the company and were replaced by one or more new persons). Second, the dependent variable enlargement shows whether the size of the executive team increased without any of the initial team members having been removed. Third, the variable reduction captures whether the number of executives declined without a new executive being installed. According to these definitions, the categories no change, replacement, enlargement, and reduction are mutually exclusive. We concentrate only on the first change within the original founding team. After the first change,

\footnotetext{
2 This share might appear to be very low. There are at least two reasons: First, our definition of these companies is fairly broad since it is based on industry NACE codes. Some of the industries may include companies which cannot be classified as high-tech and typically are not financed by venture capital. Second, our companies are 5.2 years old on average at the end of the sample period. Some of the younger companies, which are classified as non-venture-backed in our sample, may obtain venture capital in later stages of their development (after the end of our sample period).

3 The time lag issue also raises concerns about the speed of information updates when it comes to reporting a change in the executive team. Therefore, we contacted a randomly chosen sample of 50 companies in order to obtain information on the executive team. We found out that all but one of the recent changes in the team of executives had been registered by Creditreform within the following six months. Hence, this problem seems to be negligible.
} 
Table 2

Summary statistics.

\begin{tabular}{|c|c|c|c|c|}
\hline Variable & Whole sample & VC sample & Non-VC sample & $p$-value \\
\hline No. of obs. & 46,459 & 659 & 45,800 & \\
\hline Replacement & 0.1672 & 0.2777 & 0.1656 & $0.0000^{* * * *}$ \\
\hline Enlargement & 0.0744 & 0.1775 & 0.0729 & $0.0000^{* * *}$ \\
\hline Reduction & 0.0916 & 0.1502 & 0.0908 & $0.0000^{* * *}$ \\
\hline Time until replacement & $\begin{array}{c}3.0753 \\
(2.0009)\end{array}$ & $\begin{array}{c}2.4372 \\
(1.6053)\end{array}$ & $\begin{array}{c}3.0907 \\
(2.0070)\end{array}$ & $0.0000^{* * *}$ \\
\hline Time until enlargement & $\begin{array}{c}2.9988 \\
(2.0446)\end{array}$ & $\begin{array}{c}2.5641 \\
(1.6886)\end{array}$ & $\begin{array}{c}3.0141 \\
(2.0545)\end{array}$ & $0.0096^{* * *}$ \\
\hline Time until reduction & $\begin{array}{c}3.2021 \\
(1.9282)\end{array}$ & $\begin{array}{c}2.5454 \\
(1.5732)\end{array}$ & $\begin{array}{c}3.2177 \\
(1.9333)\end{array}$ & $0.0003^{* * *}$ \\
\hline Acad & 0.4381 & 0.4158 & 0.4385 & 0.2438 \\
\hline Executive team & $\begin{array}{c}1.3926 \\
(0.6362)\end{array}$ & $\begin{array}{c}1.6388 \\
(0.8630)\end{array}$ & $\begin{array}{c}1.3890 \\
(0.6316)\end{array}$ & $0.0000^{* * *}$ \\
\hline Initial size & $\begin{array}{c}3.4487 \\
(3.6975)\end{array}$ & $\begin{array}{c}5.8562 \\
(5.4131)\end{array}$ & $\begin{array}{c}3.4147 \\
(3.6563)\end{array}$ & $0.0000^{* * *}$ \\
\hline Initial rating & $\begin{array}{l}275.7958 \\
(58.0517)\end{array}$ & $\begin{array}{c}285.8066 \\
(98.9810)\end{array}$ & $\begin{array}{l}275.6548 \\
(57.2558)\end{array}$ & $0.0000^{* * *}$ \\
\hline East & 0.2004 & 0.2838 & 0.1992 & $0.0000^{* * *}$ \\
\hline Vc share & & $\begin{array}{c}47.5216 \\
(27.0536)\end{array}$ & & \\
\hline Gov & & 0.2589 & & \\
\hline Same district & & 0.3407 & & \\
\hline
\end{tabular}

This table gives the means and standard deviations (in parentheses) of our variables for the whole sample and for the subsamples of venture-backed and nonventure-backed companies. The last column depicts the $p$-values of $t$-tests on the equality of means (for binary variables, we use the Wilcoxon rank-sum test). For variable definitions see Table 1 . Three asterisks indicate significance at the $1 \%$ level.

the company is removed from our sample. In each year of the firm's lifetime in our sample (company-year), our dependent variable takes a value of 0 if the composition of the original founding team remained unchanged during this year. ${ }^{4}$

In approximately one third of the companies, we identify a change in the initial executive team during our sample period. In most cases (16.7\%), a part of the team is replaced. 7.4\% of the companies enlarge the executive team without dismissing any of the members. Finally, in $9.2 \%$ of the cases, the teams shrink. There are significant differences between venture-backed and nonventure-backed companies. As expected, we find more dynamics in venture-backed companies. In over $60 \%$ of venture-backed companies, a change in the initial team can be observed (in comparison to only $33 \%$ within the group of non-venture-backed companies). The percentage of each of the three alternative types of change (replacement, enlargement, reduction) is significantly higher for venture-backed companies. Also, at about 2.5 years, compared to more than 3 years after the birth of the company on average, changes occur faster in venture-backed than in non-venture-backed companies.

Changes in the executive team composition, however, might vary systematically depending on company and industry characteristics and are not necessarily the result of the VC's impact. Thus, when analyzing the impact of VCs on changes in the executive teams, we include several control variables capturing the size of the executive team at the founding date, the education level of its members and various company characteristics such as growth, rating, location, age, year and industry. In the following, we present the reasoning behind our choice of control variables.

We expect that a larger initial executive team results in a higher probability of executive turnover, simply because the probability that somebody will be replaced is higher. Moreover, a smaller team may tend to be enlarged and vice versa. The average initial executive team consists of 1.4 people. In addition, we control for the know-how of the founding executive team by looking at its members' educational background, checking in particular whether at least one of the executives is a university graduate (dummy variable acad).

We further assume that companies with high growth rates tend to replace or enlarge their executive teams more often, since a dynamic company may change or add some new tasks for the executive team. To fulfil these challenges, new skills may be needed. In contrast, negative growth rates may lead to dismissals, i.e. to a reduction in the team size, since a bad performance is often seen as the fault of executives. For each year, we use the growth in the number of employees since the birth of the company up to the respective year. The average initial size is 3.4 employees. We also control for the companies' rating, which reaches a score of 276 on average (100 is the best, 500 the worst rating) at birth date. The analyses in the following sections focus in particular on how a worsening of the rating affects changes in the management teams. We conjecture that a deterioration in the rating score may induce dismissals (i.e. have a positive influence on the probability of replacement and reduction) because it may also reflect poor

\footnotetext{
${ }^{4}$ One might be concerned with how we deal with the replacement of one VC representative by another VC representative. Since we consider only the first change within the initial team, this situation potentially occurs only if the following two conditions hold: (1) The company has already obtained venture capital at its foundation or before. (2) The VC has influenced the composition of the initial team. Our data do not enable us to verify the second condition. However, when we exclude those companies fulfilling the first condition, our results do not change substantially.
} 
Table 3

Multinomial logit model for the whole sample.

\begin{tabular}{|c|c|c|c|}
\hline & Replacement & Enlargement & Reduction \\
\hline$\overline{V c}$ & $\begin{array}{l}0.0048^{* * *} \\
(0.0018)\end{array}$ & $\begin{array}{l}0.0083^{* * *} \\
(0.0021)\end{array}$ & $\begin{array}{l}0.0002 \\
(0.0008)\end{array}$ \\
\hline Growth & $\begin{array}{l}0.0004 * * * \\
(0.0001)\end{array}$ & $\begin{array}{l}0.0008 * * * \\
(0.0001)\end{array}$ & $\begin{array}{l}-0.0002 * * * \\
(0.0001)\end{array}$ \\
\hline Worse rating & $\begin{array}{l}0.0062^{* * *} \\
(0.0011)\end{array}$ & $\begin{array}{l}-0.0012^{* *} \\
(0.0005)\end{array}$ & $\begin{array}{l}0.0023 * * * \\
(0.0006)\end{array}$ \\
\hline Acad & $\begin{array}{l}-0.0019^{* * * *} \\
(0.0004)\end{array}$ & $\begin{array}{l}0.0010 \text { *** } \\
(0.0003)\end{array}$ & $\begin{array}{l}0.0001 \\
(0.0002)\end{array}$ \\
\hline Executive team & $\begin{array}{l}0.0036^{* * *} \\
(0.0005)\end{array}$ & $\begin{array}{l}-0.0025^{* * *} \\
(0.0004)\end{array}$ & $\begin{array}{l}0.0062^{* * *} \\
(0.0008)\end{array}$ \\
\hline Age & $\begin{array}{l}-0.0010^{* * * *} \\
(0.0001)\end{array}$ & $\begin{array}{l}-0.0007^{* * * *} \\
(0.0001)\end{array}$ & $\begin{array}{l}-0.0004^{* * *} \\
(0.0001)\end{array}$ \\
\hline East & $\begin{array}{l}0.0034 * * * \\
(0.0006)\end{array}$ & $\begin{array}{l}0.0008^{* *} \\
(0.0004)\end{array}$ & $\begin{array}{l}0.0007^{* * *} \\
(0.0003)\end{array}$ \\
\hline $\begin{array}{l}\text { Industry dummies } \\
\text { Year dummies }\end{array}$ & & $\begin{array}{l}\text { Included } \\
\text { Included }\end{array}$ & \\
\hline $\begin{array}{l}\text { Log likelihood } \\
\text { Number of company-years } \\
\text { Number of companies } \\
\text { Pseudo- } R^{2} \\
\text { Wald } \chi^{2}\end{array}$ & & $\begin{array}{l}-37765.0 \\
152751 \\
38961 \\
0.1142 \\
4039.49 * * *\end{array}$ & \\
\hline
\end{tabular}

This table depicts the marginal effects of the multinomial logit model for the different types of change (replacement, enlargement and reduction; base category: no change). Marginal effects are calculated at sample means. The unit of observation is the company-year. Robust standard errors clustered by companies are in brackets. For variable definitions see Table 1. Marginal effects on industry dummies and year dummies are not depicted. The Hausman test of the IIA condition shows that the odd ratios are independent of other alternatives. Two and three asterisks indicate significance at the $5 \%$ and $1 \%$ level respectively.

decisions by the executive team, whereas a good or even an improved rating reveals that the company is in good condition. Furthermore, we establish whether the company is located in Eastern Germany (east).

There are significant differences between the two subsamples. Venture-backed companies are larger, have larger executive teams and are more often located in Eastern Germany. ${ }^{5}$

\section{VCs and executive turnover}

Are VCs more prone than other investors to induce changes in the executive team? To answer this question we analyze the impact of venture capital funding on the probabilities of replacement, enlargement and reduction within the initial executive team and on the time it takes for these changes to occur.

We observe the companies in our data set for several points in time which differ for each company. For some companies, all annual data on employment and rating are available. However, for the majority of our companies, we have to deal with missing observations for some company-years. Therefore, to investigate our hypotheses, we pool our data and use cross-sectional methods, taking each available combination of company and year as one individual observation. In order to capture the "panel" structure of the data, we include year dummies and cluster the error terms by company. Year dummies also control for the effects of the overall economic development.

The first part of our analysis in this section is devoted to testing whether obtaining venture capital is associated with a higher probability of replacement, enlargement and reduction within the initial executive team. In order to accurately represent the set of potential changes, we estimate a multinomial logit (MNL) model with equations for replacement, enlargement and reduction. For identification issues, one choice equation (no change) is left out and represents the so-called reference category for the computation of odd ratios. As the estimator is inconsistent if the odd ratios are not independent of the other alternatives, we also run a Hausman test which shows whether the independence from irrelevant alternatives (IIA) holds (see Greene, 2003). In our context, the Hausman test clearly confirms that the IIA holds.

The multinomial logit regression does not take into account the timing of the changes. Therefore, in the second part of our analyses within the whole sample, we investigate the time until replacement, enlargement and reduction with a duration regression approach. We use three Cox proportional hazard rate (CHR) models with independent variables time until replacement, time until enlargement and time until reduction, which measure the period between birth and the first change in the respective category. Each regression involves companies without any change within our whole sample period and companies with the respective change (e.g. when analyzing the time until replacement, companies with enlargement and reduction are excluded from the regression).

The results of the MNL and the CHR models depicted in Tables 3 and 4 are in line with the assumption that VCs are actively involved in the management of the companies they fund and, thus, are more prone to provoke changes in the initial executive

\footnotetext{
5 The relatively high share of venture-backed companies in Eastern Germany (2\% in comparison to $1.3 \%$ in the Western Germany) is primarily the result of activities of governmental VCs, which are involved in $49 \%$ of venture-backed high-tech companies in Eastern Germany, but only in $22 \%$ in Western Germany.
} 
Table 4

Cox regression for the whole sample.

\begin{tabular}{|c|c|c|c|}
\hline & Time until replacement & Time until enlargement & Time until reduction \\
\hline \multirow[t]{2}{*}{$\overline{V c}$} & $1.4880^{* * *}$ & $2.5649 * * *$ & 1.2717 \\
\hline & $(0.1664)$ & $(0.3436)$ & $(0.1920)$ \\
\hline \multirow[t]{2}{*}{ Growth } & $1.0393 * * *$ & $1.1681^{* * *}$ & $0.9647 * *$ \\
\hline & $(0.0102)$ & $(0.0108)$ & $(0.0161)$ \\
\hline \multirow[t]{2}{*}{ Worse rating } & $1.5959 * * *$ & $0.8027^{* *}$ & $1.4490^{* * *}$ \\
\hline & $(0.0881)$ & $(0.0889)$ & $(0.1124)$ \\
\hline \multirow[t]{2}{*}{ Acad } & $0.8464 * * *$ & $1.1811^{* * *}$ & $1.0861^{*}$ \\
\hline & $(0.0274)$ & $(0.0551)$ & $(0.0494)$ \\
\hline \multirow[t]{2}{*}{ Executive team } & $1.4853^{* * *}$ & $0.7581 * * *$ & $2.8085^{* * *}$ \\
\hline & $(0.0339)$ & $(0.0427)$ & $(0.1278)$ \\
\hline \multirow[t]{2}{*}{ East } & $1.3528 * * *$ & $1.1857 * * *$ & $1.1281^{*}$ \\
\hline & $(0.0510)$ & $(0.0673)$ & $(0.0837)$ \\
\hline Industry dummies & & Included & \\
\hline Year dummies & & Included & \\
\hline Log likelihood & -38589.9 & -18087.5 & -24363.7 \\
\hline Number of company-years & 141143 & 136151 & 137945 \\
\hline Number of companies & 34251 & 32083 & 32881 \\
\hline Wald $\chi^{2}$ & $1033.15^{* * *}$ & $707.49 * * *$ & $976.94 * * *$ \\
\hline
\end{tabular}

This table depicts the hazard ratios from the Cox regression with time-varying covariates. The dependent variables are time until replacement, time until enlargement and time until reduction. Each regression involves companies without change and companies with the respective change (i.e. companies with the other two categories of changes are excluded). All observations for which change does not occur are treated as censored events. Robust standard errors clustered by companies are in brackets. For variable definitions see Table 1. Hazard ratios on industry dummies and year dummies are not depicted. One, two and three asterisks indicate significance at the $10 \%, 5 \%$ and $1 \%$ level respectively.

team. The results of the multinomial logit and the duration analysis support a significantly positive impact of VC financing on replacement and enlargement of the executive team. The marginal effects of the MNL model are fairly small: 0.5 percentage points for replacement and 0.8 percentage points for enlargement. ${ }^{6}$ For the CHR models we also find a significant positive effect of VC financing on replacement and enlargement, which suggests that VC-backed companies experience a change in the initial executive team earlier than non-venture-backed companies. A hazard ratio of 1.5 in Table 4 indicates that, given that no replacement has occurred until that time, the presence of a venture capitalist raises the probability of a replacement by nearly $50 \%$. The VC's impact on the team enlargement is even stronger with the hazard ratio of 2.6, meaning that these companies are 2.6 times more likely to enlarge their teams than their non-venture-backed counterparts.

With respect to our control variables, we find that company growth has a significant impact on changes within the initial team. More dynamic companies also experience more dynamics in their executive teams. The probability of replacement and enlargement increases, and these events occur sooner, in companies with higher growth rates. This may be a hint that fast growing companies provide changing challenges for their executive teams. As one would expect, if the company gets smaller, the probability of a reduction in the size of the executive team also increases. This seems logical, since negative growth rates may point to difficulties the companies are experiencing, which may be a result of inefficiencies in the executive team. A deterioration in a company's rating increases the chances of replacement and reduction, but has a negative impact on team enlargement. Hence, in companies with constant or improving rating scores, the initial executives are typically not dismissed (and, eventually, replaced), but rather the teams are enlarged since a good rating score signals that the companies are in good condition and that the management has taken the right decisions.

The educational background of the executive team also influences the probability and the speed of change. In the MNL and the CHR models, the presence of a university graduate in the executive team has a significant negative effect on replacement and a positive one on enlargement. An intuitive explanation for this finding could be that founding teams with at least one graduate have good know-how and team composition, so none of the team members has to be replaced. If specific know-how is missing then a new member is appointed to the team.

Furthermore, the size of the founding executive team positively influences the probability and the speed of replacement and reduction and, as expected, decreases the probability and the speed of enlargement. With increasing company age, the probability of changes within the initial team becomes lower. In Eastern Germany, teams are changed more frequently and within shorter time periods.

\section{Endogeneity of venture capital financing}

In this section, we take into account the potential endogeneity of VC financing. A VC's involvement is often seen to be nonexogenous (e.g. Sorensen, 2007) since the decision to invest in a promising venture is not randomly taken, but instead depends on the availability of venture capital, the willingness of a company to apply for this kind of financing and, finally, on a thorough due

\footnotetext{
${ }^{6}$ Overall low marginal effects reflect the fact that our estimates are based on company-years, which means that we inflate the number of observations for companies without changes. If, for example, we observe a company in which the replacement occurs in the fifth period, we "generate" four observations with no change and only one observation with a change.
} 
Table 5

Two-step multinomial logit model with access to vc and supply.

\begin{tabular}{|c|c|c|c|c|}
\hline & Replacement & Enlargement & Reduction & Probit for $v c$ \\
\hline$\widehat{V c}$ & $\begin{array}{l}0.0069 * * * \\
(0.0021)\end{array}$ & $\begin{array}{l}0.0013^{*} \\
(0.0008)\end{array}$ & $\begin{array}{l}0.0013^{* *} \\
(0.0006)\end{array}$ & \\
\hline Number $v c$ & & & & $\begin{array}{l}0.0581^{* * *} \\
(0.0109)\end{array}$ \\
\hline Access to $v \mathrm{c}$ & & & & $\begin{array}{l}0.0001^{* * *} \\
(0.0000)\end{array}$ \\
\hline Growth & $\begin{array}{l}0.0000 \\
(0.0001)\end{array}$ & $\begin{array}{l}0.0008^{* * * *} \\
(0.0002)\end{array}$ & $\begin{array}{l}-0.0003^{* * *} \\
(0.0001)\end{array}$ & $\begin{array}{l}0.0009 * * * \\
(0.0002)\end{array}$ \\
\hline Worse rating & $\begin{array}{l}0.0009 \\
(0.0010)\end{array}$ & $\begin{array}{l}-0.0017^{* * * *} \\
(0.0006)\end{array}$ & $\begin{array}{l}0.0012 * * \\
(0.0006)\end{array}$ & $\begin{array}{l}0.0220 \text { *** } \\
(0.0033)\end{array}$ \\
\hline Acad & $\begin{array}{l}-0.0011^{* *} \\
(0.0005)\end{array}$ & $\begin{array}{l}0.0011^{* * *} \\
(0.0003)\end{array}$ & $\begin{array}{l}0.0002 \\
(0.0002)\end{array}$ & $\begin{array}{l}-0.0019 * * \\
(0.0009)\end{array}$ \\
\hline Executive team & $\begin{array}{l}0.0026 * * * \\
(0.0007)\end{array}$ & $\begin{array}{l}-0.0027^{* * *} \\
(0.0006)\end{array}$ & $\begin{array}{l}0.0060 \text { *** } \\
(0.0014)\end{array}$ & $\begin{array}{l}0.0024^{* * *} \\
(0.0006)\end{array}$ \\
\hline East & $\begin{array}{l}0.0009 \\
(0.0007)\end{array}$ & $\begin{array}{l}0.0004 \\
(0.0004)\end{array}$ & $\begin{array}{l}0.0002 \\
(0.0003)\end{array}$ & $\begin{array}{l}0.0114^{* * *} \\
(0.0019)\end{array}$ \\
\hline Age & $\begin{array}{l}-0.0010^{* * *} \\
(0.0003)\end{array}$ & $\begin{array}{l}-0.0007^{* * *} \\
(0.0002)\end{array}$ & $\begin{array}{l}-0.0004^{* * *} \\
(0.0001)\end{array}$ & $\begin{array}{l}0.0002 \\
(0.0002)\end{array}$ \\
\hline Industry dummies & & Included & & Included \\
\hline Year dummies & & Included & & Included \\
\hline Log likelihood & & -37758.8 & & -8280.5 \\
\hline Number of company-years & & 152751 & & 152751 \\
\hline Number of companies & & 38961 & & 38961 \\
\hline Pseudo- $R^{2}$ & & 0.1143 & & 0.1216 \\
\hline Wald $\chi^{2}$ & & $4047.44^{* * *}$ & & $506.60 * * *$ \\
\hline Instrument strength test $(F)$ & & & & $58.08 * * *$ \\
\hline
\end{tabular}

This table depicts the marginal effects of the multinomial logit model for the different types of change (replacement, enlargement, reduction; base category: no change) in the first three columns and the marginal effects of the first stage probit estimation in the last column. The estimation of the multinomial logit model includes the predicted value of $v c$ from the first stage probit estimation (labeled as $\widehat{v c}$ ). Marginal effects are calculated at the sample means. The unit of observation is the company-year. Robust standard errors clustered by companies (probit model) and bootstrapped (multinomial logit model) are in brackets. For variable definitions see Table 1. Marginal effects on industry and year dummies are not depicted. The Hausman test of the IIA condition shows that the odd ratios are independent of other alternatives. One, two and three asterisks indicate significance at the $10 \%, 5 \%$ and $1 \%$ level respectively.

diligence process during which the VC tries to elicit its expected future returns. We attempt to capture this endogeneity issue with the help of a two-step approach. In the first step, we investigate the determinants of the VC financing by estimating a probit model. In the second step, we employ a multinomial logit (MNL) model including the predicted values $\widehat{v c}$ from the first step regression instead of using $v c$. We bootstrap the standard errors in order to correct for their reduction caused by the inclusion of a predicted regressor in the MNL model estimation.

For identification, we need instruments which meet the exclusion restriction. These instruments should be highly correlated with the VC's investment decision but uncorrelated with the decision to induce changes within the executive team. It is a wellknown fact that venture capital activities are regionally clustered. Empirical evidence for Germany can be found e.g. in Engel (2004). We conjecture that the probability of obtaining venture capital rises with an increasing number of venture capital providers located nearby (see e.g. Sorenson and Stuart, 2001). Hochberg (2008) uses the amount of money invested in companies' local area as instrument. Since we do not have information on investment amounts, we use the number of VCs in the local area to construct our instruments, reflecting the local density of the venture capital supply.

Our first instrument, access to $v c$, is defined as the number of VCs divided by the number of high-tech start-ups in the same district as the company under focus. The advantage of this instrument is that we are able to control for the potential demand for venture capital in a region. However, for companies and VCs located near or at the district boundaries, the supply and the demand in the neighboring district, which is not considered in this measure, is probably far more relevant than in more distant areas of their own district. Therefore, our second instrument, number $v c$, reflects the number of VCs within a $50 \mathrm{~km}$ radius from the individual company. The advantage of this instrument is that all potential venture capital suppliers located in the company's vicinity are taken into consideration. However, in contrast to the first measure, this instrument ignores the potential investment opportunities competing for local venture capital. Both instruments are expected to have a positive impact on obtaining venture capital, but obviously do not affect the probability of change within executive teams.

The results of our estimation are presented in Table 5. As shown in the last column in this table, where we display the effects of the first stage probit models, both instruments have a highly significant positive impact on the probability of venture capital funding. The F-test on the joint significance of our instruments delivers a value of 58.08, which is much higher than the critical value of 10 for the instrument strength diagnostics suggested by Staiger and Stock (1997).

The first three columns in both tables display the results of the MNL model for the three types of change (replacement, enlargement, and reduction) using the same specification as in Section 4, but - instead of $v c$ - including the predicted values $\widehat{v c}$ from the probit regression. When correcting for the endogeneity of venture capital financing in this manner we find a significant positive effect of VCs on the probability of any kind of change. The economic effect of venture capital financing differs for the three 
change categories. In venture-backed companies, the occurrence of a replacement (enlargement, reduction) is 0.7 (0.1, 0.1) percentage points more likely than in non-venture-backed companies in the respective company-year. These findings confirm our results from the previous section that venture capital financing increases the probability of changes within the initial executive team. As regards the control variables, the results are very similar with respect to significance and signs.

To check the robustness of our results, we also conduct a propensity score matching where each VC-backed company is matched to a similar non-VC-backed one for each year of observation. The propensity score is calculated based on a probit model, in which the VC's decision to invest depends on growth, rating change, company age, size, the educational level of the initial executive team, the Eastern Germany dummy as well as our instruments (access to $v c$, number $v c$ ). Due to a low number of observations for several year-industries, we are not able to match companies within both the same industry and the same year. Instead of this, we use two alternative approaches: First, we match companies within the same industry while using year dummies in the propensity score regression. Second, we match companies within the same year and employ industry dummies in the propensity score regression. The results for the differences in the incidence of replacement, enlargement and reduction are very similar for both approaches. The findings of the matching approach suggest that VCbacked companies experience approximately 3\% more replacement and enlargement (both effects are highly statistically significant) and confirm our previous results. As mentioned above, we use matching only as a robustness check because we doubt that we are able to capture every factor that impacts the VC's decision to invest. Consequently, we probably still have selection on unobservables which renders the matching estimator inconsistent. We therefore do not present these results in more detail.

\section{Do the VC's characteristics matter?}

In the next step, we turn to the VC sample and analyze the impact of different characteristics of the venture capital financing on the different types of change within the initial executive team.

As in the previous section, we run a multinomial logit (MNL) model and Cox hazard rate (CHR) analyses to investigate whether and when the executive team structure changes and which type of adjustment (replacement, enlargement, reduction) occurs. We replace the VC dummy with the regressors $v c$ share (capturing the size of the initial stake VCs hold in the company), gov (indicating whether the company is financed only by governmental VCs) and same district (capturing geographical proximity). All control variables remain the same as in the previous section. The results of the MNL model are depicted in Table 6 and the results of the CHR models can be found in Table 7.

Table 6

Multinomial logit model for the VC sample.

\begin{tabular}{|c|c|c|c|}
\hline & Replacement & Enlargement & Reduction \\
\hline Vc share & $\begin{array}{l}0.0003 * \\
(0.0002)\end{array}$ & $\begin{array}{l}0.0000 \\
(0.0001)\end{array}$ & $\begin{array}{l}-0.0000 \\
(0.0000)\end{array}$ \\
\hline Gov & $\begin{array}{l}-0.0076 \\
(0.0094)\end{array}$ & $\begin{array}{l}-0.0067 \\
(0.0066)\end{array}$ & $\begin{array}{l}0.0004 \\
(0.0003)\end{array}$ \\
\hline Same district & $\begin{array}{l}0.0090 \\
(0.0097)\end{array}$ & $\begin{array}{l}0.0129 * \\
(0.0078)\end{array}$ & $\begin{array}{l}0.0008^{* *} \\
(0.0003)\end{array}$ \\
\hline Age & $\begin{array}{l}-0.0121^{* * *} \\
(0.0035)\end{array}$ & $\begin{array}{l}-0.0036 \\
(0.0024)\end{array}$ & $\begin{array}{l}-0.0002^{*} \\
(0.0001)\end{array}$ \\
\hline Growth & $\begin{array}{l}0.0014 \\
(0.0016)\end{array}$ & $\begin{array}{l}0.0023^{* *} \\
(0.0010)\end{array}$ & $\begin{array}{l}0.0000 \\
(0.0000)\end{array}$ \\
\hline Worse rating & $\begin{array}{l}0.0105 \\
(0.0113)\end{array}$ & $\begin{array}{l}-0.0049 \\
(0.0091)\end{array}$ & $\begin{array}{l}-0.0000 \\
(0.0003)\end{array}$ \\
\hline Acad & $\begin{array}{l}-0.0090 \\
(0.0085)\end{array}$ & $\begin{array}{l}0.0050 \\
(0.0074)\end{array}$ & $\begin{array}{l}0.0002 \\
(0.0003)\end{array}$ \\
\hline Executive team & $\begin{array}{l}0.0131^{* *} \\
(0.0060)\end{array}$ & $\begin{array}{l}-0.0080 \\
(0.0056)\end{array}$ & $\begin{array}{l}0.0008^{* * *} \\
(0.0002)\end{array}$ \\
\hline East & $\begin{array}{l}-0.0153^{*} \\
(0.0092)\end{array}$ & $\begin{array}{l}-0.0066 \\
(0.0070)\end{array}$ & $\begin{array}{l}-0.0001 \\
(0.0002)\end{array}$ \\
\hline $\begin{array}{l}\text { Industry dummies } \\
\text { Year dummies }\end{array}$ & & $\begin{array}{l}\text { Included } \\
\text { Included }\end{array}$ & \\
\hline $\begin{array}{l}\text { Log likelihood } \\
\text { Number of company-years } \\
\text { Number of companies } \\
\text { Pseudo- } R^{2} \\
\text { Wald } \chi^{2}\end{array}$ & & $\begin{array}{l}-650.3 \\
1622 \\
414 \\
0.1553 \\
25455.81^{* * *}\end{array}$ & \\
\hline
\end{tabular}

This table depicts the marginal effects of the multinomial logit model for the different types of change (replacement, enlargement and reduction; base category: no change). Marginal effects are calculated at sample means. The unit of observation is the company-year. Robust standard errors clustered by companies are in brackets. For variable definitions see Table 1. Marginal effects on industry dummies and year dummies are not depicted. The Hausman test of the IIA condition shows that the odd ratios are independent of other alternatives. One, two and three asterisks indicate significance at the $10 \%, 5 \%$ and $1 \%$ level respectively. 
Table 7

Cox regression for the VC sample.

\begin{tabular}{|c|c|c|c|}
\hline & Time until replacement & Time until enlargement & Time until reduction \\
\hline Vc share & $\begin{array}{l}1.0078^{*} \\
(0.0045)\end{array}$ & $\begin{array}{l}1.0008 \\
(0.0056)\end{array}$ & $\begin{array}{l}1.0029 \\
(0.0068)\end{array}$ \\
\hline Gov & $\begin{array}{l}0.7485 \\
(0.2100)\end{array}$ & $\begin{array}{l}0.7410 \\
(0.2187)\end{array}$ & $\begin{array}{l}1.7091 \\
(0.5722)\end{array}$ \\
\hline Same district & $\begin{array}{l}1.3242 \\
(0.3306)\end{array}$ & $\begin{array}{l}1.7687^{* *} \\
(0.4700)\end{array}$ & $\begin{array}{l}2.4403^{* * *} \\
(0.7050)\end{array}$ \\
\hline Growth & $\begin{array}{l}1.0388 \\
(0.0418)\end{array}$ & $\begin{array}{l}1.0855^{* *} \\
(0.0355)\end{array}$ & $\begin{array}{l}1.0857 \\
(0.0753)\end{array}$ \\
\hline Worse rating & $\begin{array}{l}1.3126 \\
(0.3415)\end{array}$ & $\begin{array}{l}0.8141 \\
(0.3277)\end{array}$ & $\begin{array}{l}0.8910 \\
(0.3984)\end{array}$ \\
\hline Acad & $\begin{array}{l}0.8518 \\
(0.2032)\end{array}$ & $\begin{array}{l}1.1762 \\
(0.3351)\end{array}$ & $\begin{array}{l}1.2615 \\
(0.4428)\end{array}$ \\
\hline Executive team & $\begin{array}{l}1.5348^{* * *} \\
(0.2020)\end{array}$ & $\begin{array}{l}0.9173 \\
(0.2021)\end{array}$ & $\begin{array}{l}4.0003^{* * *} \\
(0.6318)\end{array}$ \\
\hline East & $\begin{array}{l}0.6857 \\
(0.1776)\end{array}$ & $\begin{array}{l}0.7048 \\
(0.2013)\end{array}$ & $\begin{array}{l}0.8105 \\
(0.2673)\end{array}$ \\
\hline $\begin{array}{l}\text { Industry dummies } \\
\text { Year dummies }\end{array}$ & & $\begin{array}{l}\text { Included } \\
\text { Included }\end{array}$ & \\
\hline Log likelihood & -407.1 & -284.3 & -177.1 \\
\hline Number of company-years & 1410 & 1377 & 1333 \\
\hline Number of companies & 310 & 286 & 274 \\
\hline Wald $\chi^{2}$ & $37.76^{* * *}$ & $42.87^{* * *}$ & $157.85^{* * *}$ \\
\hline
\end{tabular}

This table depicts the hazard ratios from the Cox regression with time-varying covariates. The dependent variables are time until replacement, time until enlargement and time until reduction. Each regression involves companies without change and companies with the respective change (i.e. companies with the other two categories of changes are excluded). All observations for which change does not occur are treated as censored events. Robust standard errors clustered by companies are in brackets. For variable definitions see Table 1 . Hazard ratios on industry dummies and year dummies are not depicted. One, two and three asterisks indicate significance at the $10 \%, 5 \%$ and $1 \%$ level respectively.

In Table 6, we can see that a larger stake held by VCs is connected with a higher probability of replacement within the original executive team. A ten percentage point increase in the VCs' shareholdings is accompanied by a 0.3 percentage point increase in the probability of a replacement in a given year. A hazard ratio significantly higher than one in Table 7 indicates that the speed of replacement in the initial executive team is positively related to increasing VCs' stakes in the company. The geographical proximity has a positive impact on both the enlargement and the reduction of the team size. The hazard ratios of 1.77 (resp. 2.44 ) in Table 7 indicate that companies are nearly twice (resp. more than twice) as likely to increase (resp. reduce) the size of their executive teams if they are located in the same district as the VC. Both the multinomial logit model and the duration analysis are consistent with our Hypotheses 2 and 4a that a larger stake and geographical proximity lead to stronger involvement on the part of the VC and thus, increase the probability and the speed of a change. On the contrary, the negative impact of governmental VCs is not confirmed in our regressions.

However, the above discussed effect on the role of distance must be interpreted with caution. The VC's decision whether to finance a distant company is not necessarily exogenous, but may depend on the anticipated monitoring and involvement intensity, which is unobservable. Therefore, our finding may display two distinct effects: First, close proximity may lead to more effective monitoring and more intensive involvement as it is easier to intervene in companies located nearby than in distant companies. Second, VCs may only invest in distant companies if they expect them to be unproblematic, i.e. not to require much intervention. Put differently, they are willing to invest in problematic companies only if they are not located far away. Therefore, this correlation cannot be interpreted as a causal effect.

The majority of the control variables have the same signs as those found in the models for the whole sample, but some of them lose their significance.

\section{Conclusion}

The literature on venture capital financing in the US reveals that venture capitalists play an active role in the management of their portfolio companies. One of their strongest means of influencing company policy is to change the composition of the companies' executive teams. In our study, we test whether this means is also used by venture capitalists in Germany. Moreover, we also analyze whether a more intensive involvement of venture capitalists goes hand in hand with more frequent and faster changes in founding executive teams.

First, we find a significant positive impact of venture capitalists on the probability and the speed of change within initial executive teams in Germany. This effect of the venture capitalist's presence in a company remains robust when we account for the endogeneity of the venture capital financing. Second, our findings are consistent with the hypothesis that more intensive involvement of venture capitalists enhances the probability of change in the initial executive teams. A small distance between venture capitalists and companies and larger total stakes held by venture capitalists go along with a more intensive involvement, which makes change within the executive teams more likely and faster. 
The topic of this study deserves further investigation. Our next step will be to include performance measures in our analysis. This is a challenging task, since the causality of change and performance is ambiguous. On the one hand, a bad performance may initiate changes in the executive team. On the other hand, change may have a positive impact on the firm's subsequent performance.

\section{Appendix A. Definition of high-tech industries}

We are not able to classify high-tech companies according to technology areas, such as biotechnology or nanotechnology etc., since our data set only contains industry information on NACE codes and little text field information on technology areas.

For the manufacturing industries, we identify technology-based industries according to their industry R\&D intensity (i.e. the ratio of industry expenditures on research and development to the industry sales). To be considered a high-tech industry, an industry needs to have an R\&D intensity of at least 3.5\% (based on a classification by Grupp et al., 2000). This list is completed by knowledge-based and technology-based service sectors, e.g. R\&D facilities and software industries (based on classifications by Nerlinger, 1998; Engel and Steil, 1999). The list of these manufacturing and service sectors is given in Table 8.

Table 8

List of high-tech industries.

\begin{tabular}{|c|c|}
\hline NACE Code & Industry \\
\hline \multicolumn{2}{|c|}{ Manufacturing sectors } \\
\hline 2233 & Reproduction of computer media \\
\hline 2330 & Processing of nuclear fuel \\
\hline 2411 & Manufacture of industrial gases \\
\hline 2412 & Manufacture of dyes and pigments \\
\hline $2413 / 2414$ & Manufacture of other inorganic and organic basic chemicals \\
\hline 2417 & Manufacture of synthetic rubber in primary forms \\
\hline 2420 & Manufacture of pesticides and other agro-chemical products \\
\hline 2430 & Manufacture of paints, varnishes and similar coatings, printing ink and mastics \\
\hline 2441 & Manufacture of basic pharmaceutical products \\
\hline 2442 & Manufacture of pharmaceutical preparations \\
\hline 2461 & Manufacture of explosives \\
\hline 2462 & Manufacture of glues and gelatines \\
\hline 2463 & Manufacture of essential oils \\
\hline 2464 & Manufacture of photographic chemical material \\
\hline 2466 & Manufacture of other chemical products \\
\hline 2911 & Manufacture of engines and turbines, except aircraft, vehicle and cycle engines \\
\hline 2912 & Manufacture of pumps and compressors \\
\hline 2913 & Manufacture of taps and valves \\
\hline 2914 & Manufacture of other general purpose machinery \\
\hline 2931 & Manufacture of agricultural tractors \\
\hline 2932 & Manufacture of other agricultural and forestry machinery \\
\hline 2940 & Manufacture of machine tools \\
\hline 2952 & Manufacture of machinery for mining, quarrying and construction \\
\hline 2953 & Manufacture of machinery for food, beverage and tobacco processing \\
\hline 2954 & Manufacture of machinery for textile, apparel and leather production \\
\hline 2955 & Manufacture of machinery for paper and paperboard production \\
\hline 2956 & Manufacture of other special purpose machinery \\
\hline 2960 & Manufacture of weapons and ammunition \\
\hline 3001 & Manufacture of office machinery \\
\hline 3002 & Manufacture of computers and other information processing equipment \\
\hline 3110 & Manufacture of electric motors, generators and transformers \\
\hline 3140 & Manufacture of accumulators, primary cells and primary batteries \\
\hline 3150 & Manufacture of lighting equipment and electric lamps \\
\hline 3162 & Manufacture of other electrical equipment \\
\hline 3210 & Manufacture of electronic valves and tubes and other electronic components \\
\hline 3220 & $\begin{array}{l}\text { Manufacture of television and radio transmitters and apparatus for line telephony } \\
\text { and line telegraphy }\end{array}$ \\
\hline 3230 & $\begin{array}{l}\text { Manufacture of television and radio receivers, sound or video recording or } \\
\text { reproducing apparatus and associated goods }\end{array}$ \\
\hline 3310 & Manufacture of medical and surgical equipment and orthopaedic appliances \\
\hline 3320 & $\begin{array}{l}\text { Manufacture of instruments and appliances for measuring, checking, testing, } \\
\text { navigating and other purposes, except industrial process control equipment }\end{array}$ \\
\hline 3330 & Manufacture of industrial process control equipment \\
\hline 3340 & Manufacture of optical instruments and photographic equipment \\
\hline 3410 & Manufacture of motor vehicles \\
\hline 3430 & Manufacture of parts and accessories for motor vehicles and their engines \\
\hline 3520 & Manufacture of railway and tramway locomotives and rolling stock \\
\hline 3530 & Manufacture of aircraft and spacecraft \\
\hline
\end{tabular}


Table 8 (continued)

\begin{tabular}{ll}
\hline NACE Code & Industry \\
\hline Service sectors & \\
642 & Telecommunications \\
72 & Computer and related activities \\
731 & Research and experimental development on natural sciences and engineering \\
732 & Research and experimental development on social sciences and humanities \\
7411 & Legal activities \\
7412 & Accounting, bookkeeping and auditing activities; tax consultancy \\
7413 & Market research and public opinion polling \\
742 & Business and management consultancy activities \\
744 & Architectural and engineering activities and related technical consultancy \\
\end{tabular}

\section{Appendix B. Industry dummies}

Table 9

List of industry dummies.

\begin{tabular}{lll}
\hline Variable & NACE Code & Description \\
\hline Industry 1 & $22-24,29-35$ & High-tech manufacturing \\
Industry 2 & 642,72 & ICT services \\
Industry 3 & 73 & Research and development \\
Industry 4 & $7411-7414,744$ & Business-related services \\
Industry 5 & 742,743 & Technical services \\
\hline
\end{tabular}

\section{Appendix C. Identification of venture-backed companies}

In the ZEW Foundation Panel, there is no entry indicating whether a company has been venture-backed or not. In order to identify companies that have received venture backing, we use a computer-based search algorithm provided by Thorsten Doherr. In the first step, we create a search list including all venture capital companies that are full members of the German Private Equity and Venture Capital Association (BVK), its European (EVCA) and US counterparts (NVCA). The member lists were obtained from the websites of these associations: www.bvk-ev.de; www.evca.com; www.nvca.com. Using this search list, we then, in the second step, carry out a string search in the fields covering ownership information in the ZEW Foundation Panel.

The result of this search is a match list, in which every match of the search list with the companies in the ownership variable is listed. The match list may contain several hits for the same company from the search list, since the search algorithm allows for typographical errors, misspellings and abbreviations. The matches are hand-checked to assure high quality. The outcome of this procedure is a sample of venture-backed companies.

In the third step, we carry out an additional search for keywords such as "venture", "private equity", "seed", "start-up" within the fields covering ownership information to identify further companies with potential venture capital activities. This group is then hand-checked in order to eliminate companies that have nothing to do with venture capital, for example companies producing or selling seeds (keyword "seed".)

The VCs are then divided into two typology subgroups: private and governmental. VCs from governmental and quasigovernmental banks (such as Landesbanken) belong to the group of governmental VCs. Known private VCs, such as $3 i$ Group, and known governmental VCs, such as tbg Technologie-Beteiligungsgesellschaft, are assigned to the respective groups. All remaining VCs are hand-checked individually using internet search tools.

\section{References}

Aghion, P., Bolton, P., 1992. An incomplete contracts approach to financial contracting. Review of Economic Studies 59, $473-494$.

Almus, M., Engel, D., Prantl, S., 2000. The Mannheim Foundation Panels of the Centre for European Economic Research (ZEW. Discussion Paper 00-02, ZEWDokumentation.

Baker, M., Gompers, P.A., 2003. The determinants of board structure at the initial public offering. Journal of Law and Economics 66, 569-598.

Bergemann, D., Hege, U., 1998. Venture capital financing, moral hazard, and learning. Journal of Banking and Finance 22, 703-735.

Boone, A.L., Field, L.C., Karpoff, J.M., Raheja, C.G., 2007. The determinants of corporate board size and composition: an empirical analysis. Journal of Financial Economics 85 (1), 66-101.

Chan, Y., Siegel, D., Thakor, A.V., 1990. Learning, corporate control and performance requirements in venture capital contracts. International Economic Review 31 (2), 365-381.

Cumming, D.J., Fleming, G., Schwienbacher, A., 2008. Financial intermediaries, ownership structure and the provision of venture capital to smes: evidence from Japan. Small Business Economics 31, 59-92.

Engel, D., 2004. Venture capital für junge Unternehmen. Nomos-Verlag.

Engel, D., Steil, F., 1999. Dienstleistungsneugründungen in Baden-Württemberg. Arbeitsbericht der Akademie für Technikfolgenabschätzung. Discussion Paper 139. Engel, D., Heger, D., 2006. Direct Intervention of Public Venture Capital Companies in the German VC Market: A Microeconometric Based Answer. mimeo. 
Greene, W., 2003. Econometric Analysis, 5 ed. Prentice Hall.

Grupp, H., Jungmittag, A., Schmoch, U., Legler, H., 2000. Hochtechnologie 2000: Neudefinition der Hochtechnologie Für Die Berichterstattung Zur Technologischen Leistungsfähigkeit Deutschlands: Gutachten Für Das Bundesforschungsministerium (Bmbf). Fraunhofer ISI und NIW, Karlsruhe.

Hellmann, T.F., 1998. The allocation of control rights in venture capital contracts. Rand Journal of Economics 29, 57-76.

Hellmann, T.F., Puri, M., 2002. Venture capital and the professionalization of start-up firms: empirical evidence. Journal of Finance 57, 169-197.

Hochberg, Y., 2008. Venture capital and corporate governance in the newly public firm. Kellogg School of Management, Northwestern University, Evanston. Discussion paper.

Kaplan, S.N., Strömberg, P., 2004. Characteristics, contracts and actions: evidence from venture capitalist analyses. Journal of Finance 59 (5), $2177-2210$.

Lerner, J., 1995. Venture capitalists and the oversight of private firms. Journal of Finance 50, 301-316.

Nerlinger, E., 1998. Standorte und Entwicklung junger innovativer Unternehmen: Empirische Ergebnisse für West-Deutschland, 27 ed. ZEW Wirtschaftsanalysen, Mannheim, Baden-Baden.

Rosenstein, J., Bruno, A.V., Bygrave, W.D., Taylor, N.T., 1993. The CEO, venture capitalists, and the board. Journal of Business Venturing 8, 99-113.

Sahlman, W.A., 1990. The structure and governance of venture capital organizations. Journal of Financial Economics 27, 473-521.

Sorensen, M., 2007. How smart is smart money? A two-sided matching model of venture capital. Journal of Finance 62 (6), 2725-2762.

Sorenson, O., Stuart, T., 2001. Syndication networks and the spatial distribution of venture capital investments. American Journal of Sociology 106, $1546-1588$.

Staiger, D., Stock, J.H., 1997. Instrumental variables regression with weak instruments. Econometrica 65 (3), 557-586.

Tykvová, T., 2007. What do economists tell us about venture capital contracts? Journal of Economic Surveys 21 (1), 65-89. 